\title{
Small Non-Conventional Irrigation Dams with Open and Elongated Fields
}

\author{
Emmanuel Galindo*, Tomás Serrano, Raúl Rodarte, Tomás Hernández, Alex Manetta \\ Instituto de Ciencias Sociales y Humanidades, Universidad Autónoma del Estado de Hidalgo, Pachuca, México \\ Email: "emmanuel_galindo6175@uaeh.edu.mx
}

Received 15 March 2016; accepted 9 May 2016; published 12 May 2016

Copyright $(\underset{2016}{ } 2 \mathrm{by}$ authors and Scientific Research Publishing Inc.

This work is licensed under the Creative Commons Attribution International License (CC BY).

http://creativecommons.org/licenses/by/4.0/

(c) (1) Open Access

\begin{abstract}
The objective is to describe the hydraulic infrastructure and social organization in a small system of non-conventional irrigation locally known as presas. The technique consists in controlling runoff and retaining the soil, which has dragged with it. For that the local inhabitants must increase the height of a series of walls built with stones arranged in beds of dry streams. The information was obtained with field tours, interpretation of topographic charts and interviews with users of the presas. We conclude that the permanence of the system depends on the knowledge to control runoff, the availability of plant varieties adapted to the local ecology, the widespread use of oxen for agricultural work, as well as the social arrangements that allow the maintenance of the hydraulic infrastructure.
\end{abstract}

\section{Keywords}

Lama-Bordo, Runoff, Residual Moisture, Small Irrigation

\section{Introduction}

The study of conventional irrigation at small or large scale has a totally unresolved controversy over their government and administration, specifically about the ability of the irrigators to create institutions or organizations for the management of water and water infrastructure [1]-[13].

With such background, it is provocative to include in the debate the unconventional small-scale irrigation. Despite advances in this line of research [10], it is necessary to ask ourselves in a systematic way and with empirical cases, on the type of social organization that this type of irrigation generates, likewise document its importance for Mexican agriculture.

To contribute to such a debate, the aim of this article is to describe the hydraulic infrastructure and social or-

\footnotetext{
${ }^{*}$ Corresponding author.
}

How to cite this paper: Galindo, E., Serrano, T., Rodarte, R., Hernández, T. and Manetta, A. (2016) Small Non-Conventional Irrigation Dams with Open and Elongated Fields. Journal of Water Resource and Protection, 8, 551-567. 
ganization which control the avenues of water, which occur in the rainy season in order to practice Milpa agriculture with residual moisture.

The study area corresponds to the Saucillo, an Ejido (common land) located in the high part of the Amajac River basin, Northwest of Actopan Hidalgo, Mexico, where the landscape settles from a relief with rugged slopes, extreme deforestation and erratic rainfall (Figure 1 and Figure 2).

The technique under study is known locally as presas and its purpose is to control water runoff as well as to retain the soil that it carries, for that local people gradually increase the height of a series of walls built with stones accommodated on dry streambeds. Therefore, year after year, ejidatarios (commoners), holders of each presa, establish maize cultivation associated with beans, potatoes and squash; same which are irrigated with runoff in rainy season, flooded in a staggered manner, likewise all the artificial plains formed between each of the walls downstream.

Access to the system by local people goes back to the time of land distribution, and since then the unit of measure set for each ejidatario is the planting furrows.

As registered on field, the current demarcation between plots is made by introducing into the ground stakes line running from one end to another in the respective presas to follow the course of the furrows to establish the cultivation. With the purpose of, once the observer is located within the artificial plateau, gained from a bed of dry stream, what can be seen only, apparently, is a single plot with corn and bean plants in the same biological stage.

To address this case of small non-conventional irrigation in its fair dimension, we divided the document into nine sections. In the first, we present a quick introduction to the problems of the conventional way of methodological bridge irrigation to deal with non-conventional irrigation, the second summarizes very briefly the history of the irrigation runoff in Mexico and the third the presence of crops in open and lengthened fields in other parts of the world. Section four to eight we expose the information collected during the field work, and it makes clear the technical operation to establish the milpa in dams as well as the social organization that makes possible the permanence of the described system.

Section nine covers elements of analysis to define this system of irrigation and of non-conventional type at

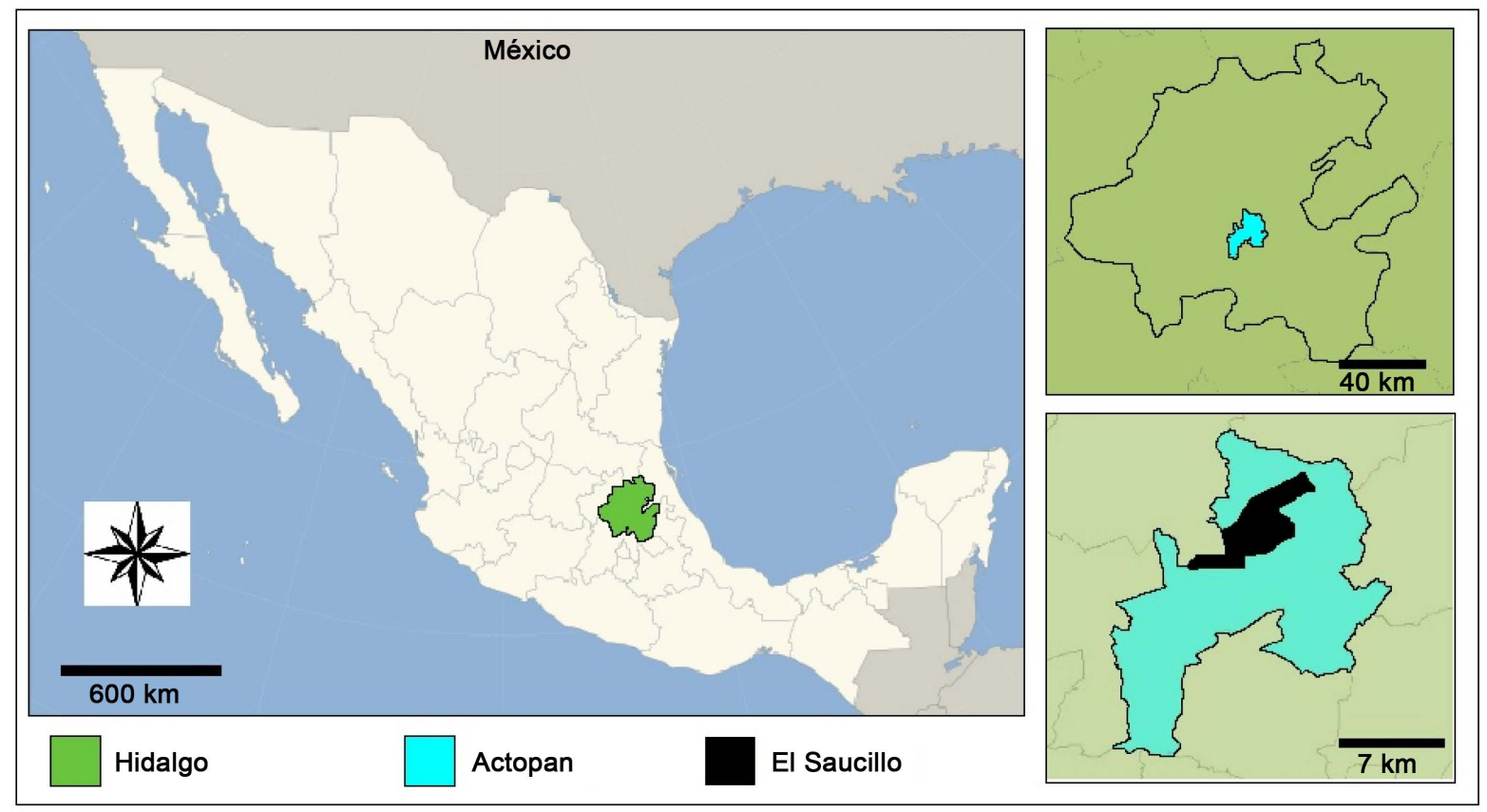

Figure 1. Ejido El Saucillo, Actopan, Hidalgo, México. Geographiclocation: 20401'3"N/988502"O; 20³929"N/988440"O; $20^{\circ} 3337^{\prime N} / 98^{\circ} 8948^{\prime \prime O} ; 20^{\circ} 3359 " N / 98^{\circ} 9298^{\prime \prime O}$. Altitude: 2100 meters above sea level. Total area: 1948.514831 hectareasor 4814.8850 acres. Total área of thethreedams: 21.853 hectareasor 54 acres. Beneficiaries: 82 ejidatarios and 11 posssesor. Prepared whit information from databases SIG and PHINA, National Agrarian Registry, 2016.

http://www.ran.gob.mx/ran/index.php/nuestros-sistemas. 


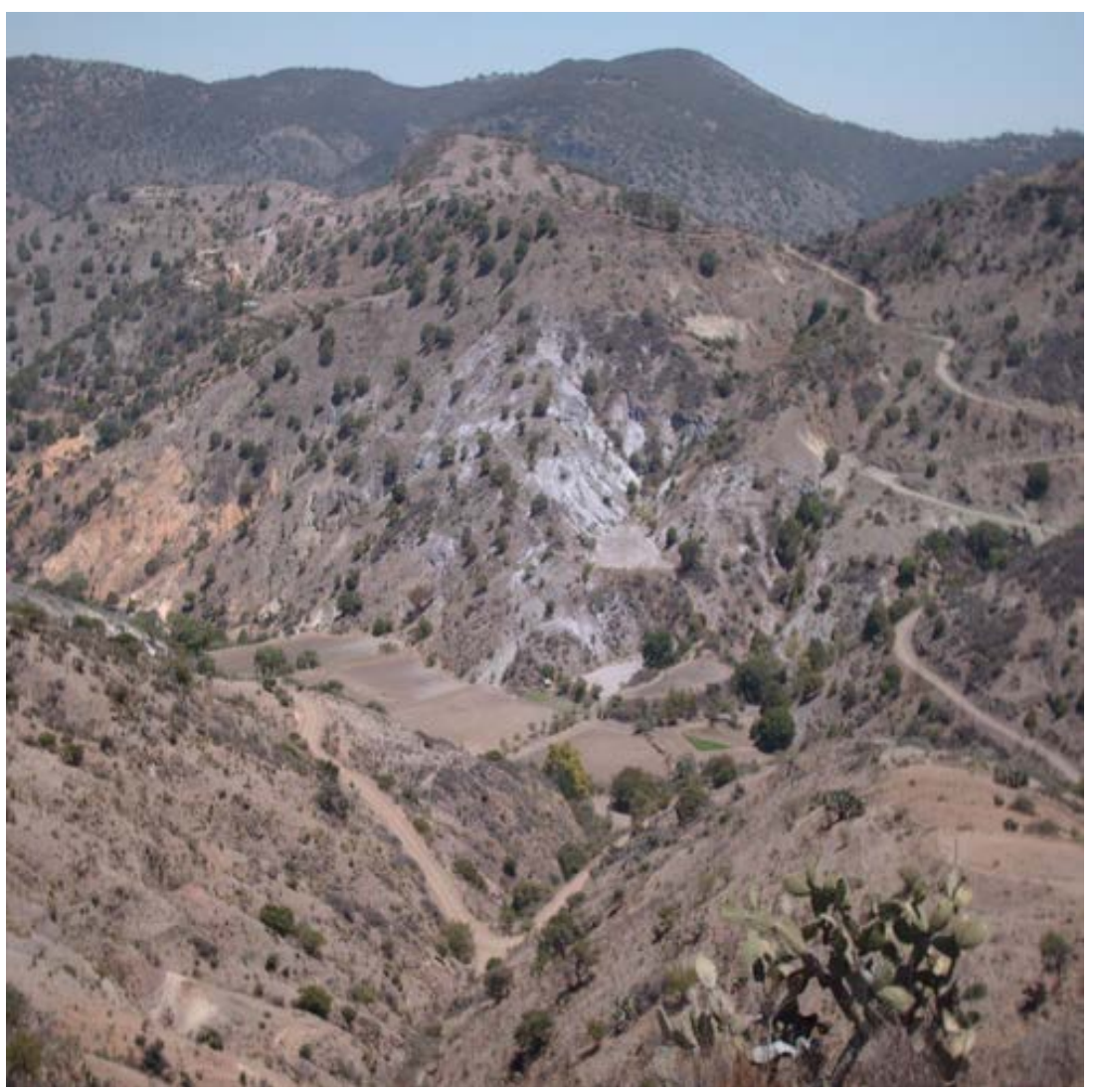

Figure 2. Landscape study area (Galindo, 2015).

small scale. Finally, the conclusions, we affirm that the continued use of such system lies in the presence of a set of local knowledge that is transmitted from one generation to another for the management of runoff, as well as the availability of plant varieties adapted to the ecology of the area of study and the widespread use of oxen for agriculture work.

\section{Canal Irrigation System: Size and Authority}

Hunt [7] debates with a previous work of Kelly [4] on the components to determine what an irrigation system is, and provides one of the most comprehensive definitions to enunciate the two parts that make up this type of system: the work of a head water intake or canal gate, and subsequent control works.

Regarding the first, Hunt [7] indicates that it serves to take water from a natural canal or headwork and divert its course downhill. For the subsequent control works, either canals, canal gates, or the same fields, it mentions that they are used to guide the water that flows on the surface towards the cultivated plants until it is absorbed by the soil or until it flows on the surface outside the scope of the same subsequent control works.

Hunt [7] mentions that there has been efforts to answer the question about the size of an irrigation system based on three criteria, the number of inhabitants contained at its borders, along the main channel or the total length of the channels, as well as the extension or total surface covered by the same system. Given the ambiguity of such criteria, he proposes that if the system is defined from a canal gate or work header and the control structures that lead to water outwards of it through its natural drainage; then its size is determined by the extension or number of hectares or acres which are irrigated from the canal gate or work header.

In another vein, Hunt [7] proposes, reflecting on the power and the difficulties to define, observe and measure in irrigation systems through channels, that the study of the centralization of control in such systems is addressed from the structure of authority for its administration. This implies the use of categories as centralized authority, decentralized authority, concentrated authority, dispersed authority and coordination with the State or autonomy from it. 
Such categories, according to Hunt [7], are essential to answer the question as to whether the authority over the decisions and activities for the management of the irrigation system are located within or outside of it. For the latter, it makes it clear that an administrative structure must contain work to be done and individuals to conduct it, and that in systems of irrigation through canals, some of the tasks are the construction of the physical system and its maintenance, the capture of water from the environment and its distribution as well as conflict resolutions and accounting.

Concerning the relationship between size and authority for management, Hunt [7] underlines that not necessarily all irrigation systems through canals must be unified, and emphasizes that there is a huge probability that when it exceeds 100 hectares (or 247.10 acres) they must have a unified system of authority structure, opposite with systems under 50 hectares (or 123.55 acres). He also warns that in such headless systems, the difficulty lies in how to perform the tasks mentioned above as well as the sharing of water in times of scarcity or punish users who benefit from the resource without participating in the execution of these tasks.

Finally, Hunt [7] concludes that systems of very small irrigation can be operated without constituting authority, some of considerable size such as 459,000 hectares (or 1,334,369 acres) can be operated by the irrigators and irrigation systems for example 700 hectares (or 1729.74 acres) can be administered by national governments.

So far we can ensure that the methodological bridge for the study of small conventional irrigation and small non-conventional irrigation discussion on the size and complexity of the system is implied, the presence or absence of a power or headwork, same as control works and the number of hectares or acres irrigated with perennial water or runoff, and finally the correlation between these variables and the authority structure.

\section{Small Non-Conventional Irrigation: Empirical Evidence}

According to the above it is clear that the conventional irrigation implies an intake or headwork that provides a constant flow of water and a set of main and secondary canals to distribute the fluid between the plots. We can also say that such systems, as constituted, can form a type of government based on irrigators or who is in charge of national states. So, the obvious question is how to define non-conventional irrigation and later small nonconventional irrigation as well as the necessary social organization for management.

In trying to establish the aforementioned situation, Palerm [10] indicates that it considers an irrigation system when you have a major water reservoir and a network of canals or a tech distribution system for example, dripping or sprinkling; by contrast, in non-conventional irrigation, the waters to be used can be rain, runoff, floodwaters, or those contained in swamps and seasonal ponds.

Therefore, non-conventional irrigation includes all agricultural practices were used, according to Palerm [10], waters that are not permanent or are not controlled by large hydraulic works and often have a network of canals for distribution.

With regard to the social organization of small irrigation compared to large irrigation, Martinez and Palerm [14] places greater emphasis on intervention or autonomy from the national state than the number of irrigated hectares or acres. The above is justified, the Mexican case, by the polarization and the opposition that exists between the large irrigation of corporate agriculture and rural farming and the seasonally cultivated land.

Against such opposition, for Palerm and Martínez [14], the methodological and operational definition of small irrigation allows to analyze the situation of this type of farmers with irrigation outside the areas of great irrigation under the following two assumptions: in the so-called great irrigation the systems were built and managed by the State prior to its transfer to irrigators; for small irrigation, irrigation systems are not administered by the State.

Small irrigation techniques are discussed in a recent publication classified as non-conventional type [15]. The richness of the gathered material is that it is not limited to the Mexican case and because the emphasis is both on permanent and more complex techniques as well as in the simple and ephemeral.

Among the first type stand entarquinamiento (siltation) in cajas de agua (water boxes), Mexican and Spanish galleríasfiltrantes (infiltration galleries), the cultivation system in gavias (ditches), and minas de aguas (water mines) in the Canary Islands as well as the qochas (natural or artificial ponds) of the Peruvian highlands. Among the simplest we findtemporary stonecercas (fences) and muros (walls) for handling gullies, the bimbalete (swape) or shaduf (swape) used to lift water from a river, canal, water reservoir, or well through a mechanism that involves balancing a stick or a long poleon a horizontal support [15].

It is documented in the same publication, for silting practice, the need to divert water from a river as well as 
the presence of canals to convey it to the plots. Regarding water mines and infiltration galleries, it is said to be used to provide light to groundwater by gravity through horizontal tunnels, and in the case gavias and qochas their only source of water is seasonal rains [15].

Other documented evidence is the huertos en vegasaluviales (system of orchards in alluvial meadows) of the Potosino plateau [16], which standouts the lift irrigation from streams or open well pits dug in river valleys and known by locals as lumbreras (vent), also, it emphasizes that it is common to use Bimbaletes (seesaw).

\section{Irrigation with Runoff: The Mexican Case}

This section is dedicated to establishing some general background on the type of irrigation we documented here, and to emphasize that such technique for agricultural production is neitherunique neither to the study area norto the contemporary period in which we studied it.

As a starting point, it is necessary to make clear that it has already been demonstrated that with surface runoffirrigation has been practiced in different places and through different historical periods.

On this issue, we can say that one of the most ancientarchaeological evidences corresponds to the desert of the Negev, in Israel, where agriculture with rainwater catchment systems was practiced, more than 4000 years ago [17]. Also the ancient inhabitants of Libya, Iraq, Syria, Jordan and Pakistan knewabout the systems for the uptake of soil and moisture retention, the same can be said for some of the so-called subcontinents such as Australia, India, the Arabian Peninsula, Africa, ancient Mesoamerica, and the current southwest of the United States and North of Mexico [18].

For the specific case of Mexico, it is pertinent to emphasize that techniques of water exploitation for irrigation, dating back to pre-Hispanic times, are referred to by different names, and that some of the most celebrated works, so far published, are those of Sanders, MacNeish, Spores, West and Donkin, respectively [19]-[23].

In this regard, Rojas [24] points out, in a categorical way, that the practice of irrigation with water from runoff in canyons corresponds to a type of terraces, generically calledas presa, and that such a technique takes on different names depending on the geographic area where they are located.

For example, in Chihuahua they are known as trincheras (trenches), in the Valle delMezquital as atajadizos (weirs), teceras (barrage) in the Valley of Mexico, and lama bordos (ckeck dams) in the Mixtec. The constant, according to Rojas [24], is that the technique consists in building a series of walls on the inside and breadthwise of a ravine or gully to retain soil and width.

Martinez [25] documented a similar type of irrigation that is described for Tlaxcala of the colonial era known as muros de barranca (ravine walls). He specifies that the technique consists of building stone walls and sticks for the retention of sediments inside the ravines, so that the spaces between the walls formed a fertile bed for agriculture practice.

Some documented cases of contemporary irrigation use with runoff corresponds to LaJollas of the OaxacanMixteca [26] and dams or embankments located southeast of mezquitalhidalguense [27]. According to information reported in both cases, the technique is to build small dams of stone on the bed of a dry stream in order to retain soil, which avenues of water carry in rainy season and to conserve humidity in the flooded area where corn is generally planted.

To conclude this section, it is worth mentioning that the archaeological studies of dams or lama boards found in the Oaxacan Mixteca report that they were used at least 3400 or 3500 years ago [28]. That is, for the Mexican case, we are dealing with a technique of ancient irrigation and despite its age and geographical distribution throughout the country; little has been studied on contemporary usage. With this, we do not want to say that the dams found in the mountains of Actopan have such antiquity, much less that they date back to pre-Hispanic times; what we emphasize is that similar technical answers were known and used elsewhere in Mexico for different historical periods.

\section{Some Notes on Open and Elongated Fields}

In this section we want to emphasize that the management of agricultural spaces under the modality of open and elongated fields was present in other parts of the world, and that some of the most documented cases correspond to the old Europe.

It is worth noting that this does not arise to establish diffusion or parallel technology and social organization among the old and the new world with regard to the presence of elongated and open fields. The intention is to 
show some documented cases and technical and social implications of the implementation of such a system of agricultural production.

Bloch [29] states, in French rural history, that such agricultural system was characterized by a successive order of crops, a set of technical procedures, and by certain principles of social organization. In addition, it clarifies that such a system was not specifically French and indicates that it also covered a considerable part of England, Germany as well as the plains of Poland or Russia.

For the French case, Bloch [29] points out that the emergence of artificial forage and tubers contributed decisively to the great revolution in the agricultural economy from the tillage and grazing association. This was due to a problem at that time, which consisted in how to feed the animals which were necessary to pull plows, it was solved partially with the invention of tillage and a correlation among grains, forest and pasture.

Another two factors that influenced that revolution were the ecology and social organization. According to Bloch [29], for the wet and heavy soil fallow, it was necessary the invention of a wheeled plough pulled by eight oxen known as carruca; and the need to manage in a coordinated manner the open and elongated fields under the triennial rotation system that consists of dividing the space to cultivate in three sections or beds; one remains since autumn sown with either wheat, spelt or rye, the second is reserved for spring cereal which can be barley, oats or forages, and the third lies fallowed a whole year.

Bloch [29] documented some of the crop characteristics in elongated and necessarily open fields for the transit of animals or people to ensure to fallow, plant, harvest or graze fields, and among them three stand out: 1) The permanence of private property which was guaranteed by sinking some boundary stones in the ground to divide each plot or each group of plots, and in the lack of them a furrow was left to establish an entirely imaginary line, 2) Rotation and mandatory coordination for those long, thin strips of agricultural land to allow the triennial rotation, 3) The mandatory opening of demesnes for grazing cattle that were maintained commonly and were necessary as draught animals as well as for the supply of meat or milk.

Under such agrarian regime, as Bolch [29] notes, French farmers faced some of the following problems: 1) How to get to one of those narrow strips bypassing the neighbor. 2) How to move from one plot to another in case they were enclosed. 3) How to feed the animals people needed to pull the carruca. To which he responds that we must pay attention to the human causes, and asserts that such a regime is possible with a great social cohesion and a community mentality.

According to the above we can say that the presence of open and elongated fields in ancient Europe had a considerable influence on the ecology and technological innovation of the carruca, however it was the cohesion and social organization that enabled their stay in the long term.

After these long references to Bloch's works [29], in the following sections we explain how factors such as the local ecology, agro-ecosystem of the cornfields, land distribution, the use of yokes, and the social organization influence in the shaping of the dam system in the study area.

\section{The Local Ecology and the Dam System in the Study Area}

The ejido polygon of ElSaucillo is located in the southwestern of the Amajac River basin slope, which is a tributary of the Moctezuma River in the highest south part of the administrative region RH26-Pánuco [30].

At the top of the indicated basin, specifically between hill elevations of the Cerro Tordillo, LaBandera, El Pardito and Cerro Blanco, originates the intermittent river Las Milpitas, on which were built walls that give rise to the ground catchment system and runoff known locally as presas.

El Piña and El Pedregal ravines are the only tributary of Las Milpitas River in this part of its course, the first originates in La Bandera hill at an altitude of 2450 meters and the second in the Pardito hill at 2500 meters. Both dry riverbeds travel from south to north a distance of approximately two kilometers in a straight line, and descends precipitously to reach until it reaches the dimension of an altitude of 2000 meters above sea level to form a single channel a few meters from a canyon that separates the Tordillo and Blanco hills [30].

Isohyets and isotherms illustrated in the consulted mapping support the conclusion that the study area has an annual rainfall of between 700 and 800 millimeters as well as a coefficient runoff of $10 \%$ to $20 \%$, and the average annual temperature is $17^{\circ} \mathrm{C}$ [31].

According to local villagers, precipitation may occur in March or May but the most abundant rain occurs from July to September and can be concentrated in two or three events throughout the annual rainfall.

This means that while the amount of water that precipitates is not small in quantity, it represents a critical re- 
source in the sense that there is little rainfall that generates runoff and that these should be retained in as much as possible.

As can be verified on a field trip, in addition to the terraces on the slopes, the only plains between that exist between the massifs that delimit the study area are formed artificially by local people with the presas technique (Figure 3 and Figure 4).

Thus, each of the agricultural areas gained from the Milpitas River has a toponymy that makes allusion to the stream where waterworks have been built on for soil retention dragged by runoff. Such that, in the final part of the course of the Pedregal ravinethere is a succession of six walls that give rise to the agricultural space called El Pedregal dam, and at the end of ElPiña ravine three walls that give origin toanother agricultural space called La Palma dam.

As mentioned, these two streams converge downstream in a single canyon that forms the Milpitas River. Right at this point El Saucillo dam is located whose last curtain wall of stone and lime, which serves as a curtain for the final eviction of the excesses, exceeds 40.0 meters high with a crown of 30.0 meters long and 5.0 on its wider part (Figure 5).

It is worth mentioning that local people report that this is the oldest dam among the three that are found in the area of study, that after the agrarian distribution, it took its name from the current human settlement, and according to Hilario Chavarria, president of the ejidal commissarial in turn, the last dam that was built was El Pedregal.

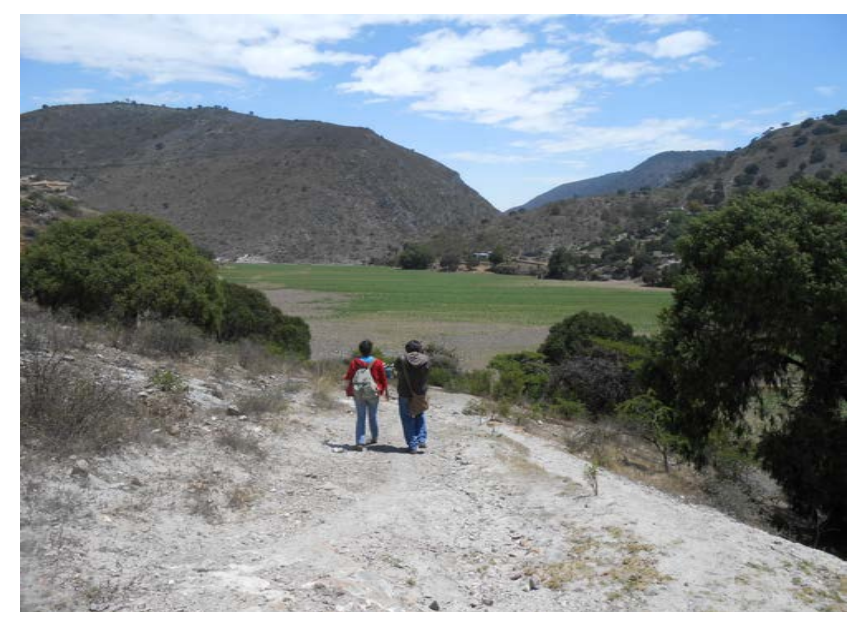

Figure 3. Upper view of a dam (Galindo 2015).

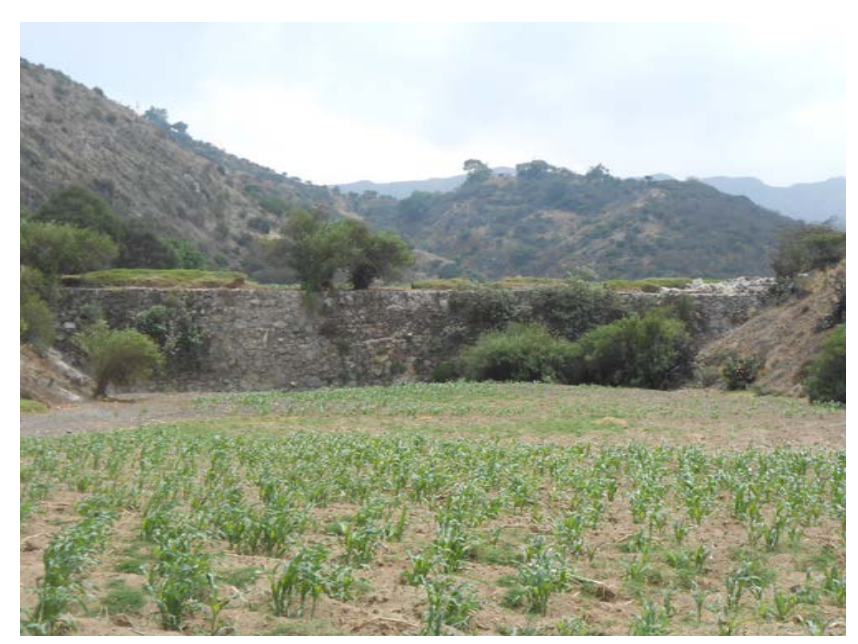

Figure 4. Front view of a wall in the interior of a dam (Galindo 2015). 


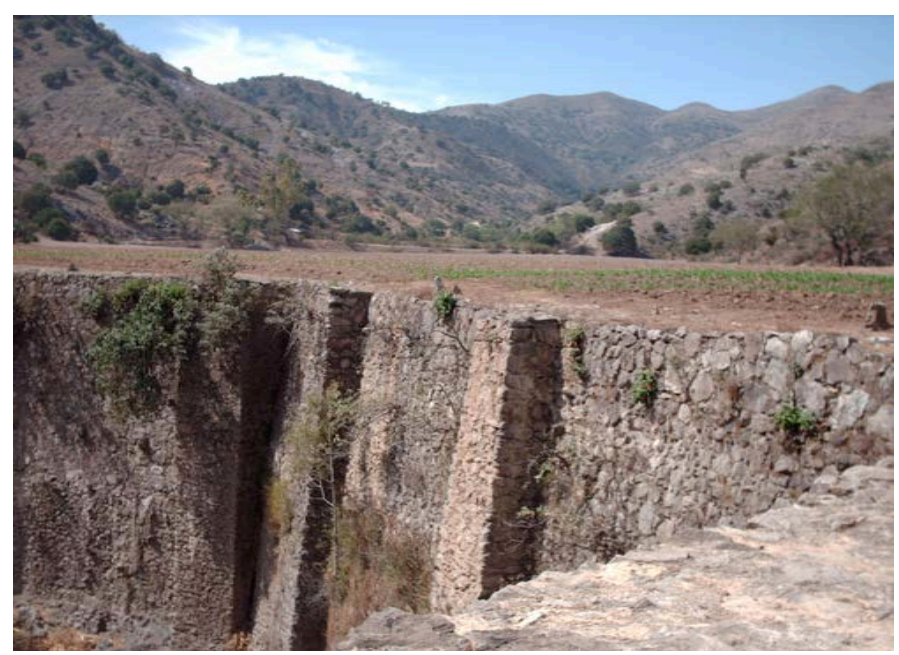

Figure 5. El Saucillo dam, spillway water curtain (Galindo 2015).

Therefore we can ensure that the conditioning of agricultural areas has been upstream. That is, once the Saucillodam was consolidated successive increases in the height of its curtain have allowed local people to raise the level of cultivated plains and returned upstream little by little, until it achieved to consolidate the other two agricultural spaces in the gullies of the El Pedregal ravines and El Piña respectively.

This could be seen on a field trip, and can also be verified that between the curtain of the Saucillodam and the point at the confluence of two tributaries there are approximately 600 linear meters per 200 at its widest part, conforming well agricultural space gained from the Milpitas River.

Such plain, according to the contours illustrated in consulted mapping [30], presents an approximate 20 meter ramp and remains between the dimensions of 1100 and 1080 meters, respectively. The other two dams, $\mathrm{El} \mathrm{Pe}$ dregal and La Palma present slopes of 10 and 15 meters and lengths of 700 and 600 meters long respectively.

For the aforementioned reasons we can say that local people have the ability and possess the necessary knowledge to handle avenues of rainwater in order to insert the runoff less violently to the cultivation fields nestled in beds of intermittent streams.

Thus, the major challenges consist of controlling flashing waters down to 400 meters of height and drive them into the dry streambeds at distances which does not exceed the two kilometers from its birth until the start of the plain into the river. And for this purpose there are strategic and quite useful waterworks that local residents called represos, which are a series of small stone walls that are built right in narrower areas and inclined at the beginning of the dry stream beds.

In the backwater of the lower parts, once the runoff has flooded the first dam and it reaches its saturation level, it begins to pour out to the second dam by the same curtain and through the right bank of the field that has a slight slope with respect to the rest and serves as a spillway.

The mechanism is repeated downstream and in stages until every wall that exist in each plain gaining from the Milpitas river, in such a way that the Saucillo dam receives the excesses from runoff from the other two and leftovers spilled through its curtain to follow its course in the canyon formed by the mentioned river and evict the total of the studied area.

\section{The Division Furrow and the Category of Partner}

For the area of study, the most recent precedent with respect to the management of the system of dams by local villagers dates from the agrarian distribution post-revolutionary the period of the agrarianism or the agraristas as referred by the local collective memory.

The stories of the elderly coincide in pointing out that in its early days the Saucillo dam was built each year with stones, sticks and dirt by orders of a Spaniard named Juan Gómez, who was the last owner of the former hacienda called La Estancia.

According to records reviewed in the ejidal archives of the town, on October 26, 1929 by means of an endowment, a total of 1948.51 hectares of cerriles land (mountainous land) were awarded to 68 residents who then 
formed the town center.

Of the initial allocation, there remain 782.11 hectares in common use, the rest went to full ownership of the current 103 ejidatarios holders by applying procedures through the Certification Program of Ejido Rights and Titling of Lots known as PROCEDE [32].

As mentioned, the affected hacienda was the La Estancia and the granted ejidalpolygon included the total of the three dams mentioned with their respective catchment systems. Therefore, after the agrarian distribution the ejidatarios of the Saucillo have as plot a small fraction of the dams and at least one more plot in the cerril part where smooth or rugged slopes predominate.

Rodrigo Perez remembers the land distribution of the plains formed within the Saucillo dam. He points out that the distribution was made in 1930 by assigning 14.5 linear meters to each one of the ejidatarios beneficiaries, and that such a surface could plant up to 30 rows of corn. He also remembered that there was no disagreement between the beneficiaries and that was the first time that the stakes were placed in the dam to divide the respective plots.

Meanwhile, the current president of the ejido refers to a reallocation of the Saucillo dam took place in 1940 because some ejidatarios did not comply with the works of maintenance of the curtain and lost their rights. He also indicates that the division was by the number of furrows and no longer per meter; the engineers of the Agricultural Department made such a prior distribution agreement between the ejidatarios in the sense of assigning a larger number to plots located in the narrowest parts of the dam, so that now each holder has 20 or 30 furrows depending on the their length.

The situation of the La Palma dam is similar to the above mentioned, but in possession of only 15 ejidatarios. The reason for exclusion is the same, the lack of participation in the maintenance of their respective walls and curtains to dislodge runoff. Opposite case happens with the Pedregal dam sinceit remains privately owned by a single family and the current owners obtained it via inheritance.

It is pertinent to draw attention to the fact that among locals, they call socio to those who are holders of one of the plots located within the Saucillo or Palmadams respectively, and identify them with this category. Therefore, when asked who is the owner they generally respond that it is of such a number of socios.

These results, in the inner core of the ejido El Saucillo, two organizational levels are present, one for the handling of the concerning fraction, that is still in common use, and includes all ejiditarios. The other for the three dams and only includes those who hold the status of socio in the possession and the concerning use.

Therefore, it can be said that the call for maintenance and rehabilitation of dams as well as its verification is in charge of the respective socios without the intervention of the ejidal commissariat in turn.

The latter was found in one of the incursions in the study area just when a section of the curtain of the Palma dam was being rehabilitated. For this, the tasks were to haul the stone needed to raise the dam; carry water to prepare the mixture with cement and lime bought previously by the socios; place the stones held together with the mixture onto the section of the curtain that was being repaired at that time; and finally fill with soil the section of the plot that the runoff took in order to level the ground and avoid its pressure on a certain point of the curtain (Figure 6).

Finally, it only remains to mention that after the implementation of PROCEED each received their respective ejidatario plot certificate accrediting him as the holder of a fraction of one of the two dams that are managed collectively. And to sayabout Hilario Chavarria, current president of the Ejido and socio of the Saucillo dam, both organizations, the Saucillo and the Pedregal dam, have been established formally before a public notary.

\section{The Milpa and Agroecosystem}

Corn is the main crop established in dams and agricultural system practiced by local villagers corresponds to the type classified by Rojas [33] as annual cycle systems with few months break.

This is due to the following factors: the intensity or frequency of the same agricultural space that is nine months from February to October; because the source of moisture is temporary and depends on annual seasonal precipitation and its ability to produce enough runoff to flood growing areas; and because agricultural practices identified on field show that corn cultivation is associated to beans, squash and potatoes, and between production cycles the soil is left to rest for at least two months for subsequent fallow.

Thus, in view of the visitor, the plains gained from the intermittent the Milpitas River present a succession of three agricultural landscapes: Furrowed fields or rayados between January and February, milpas from March to 


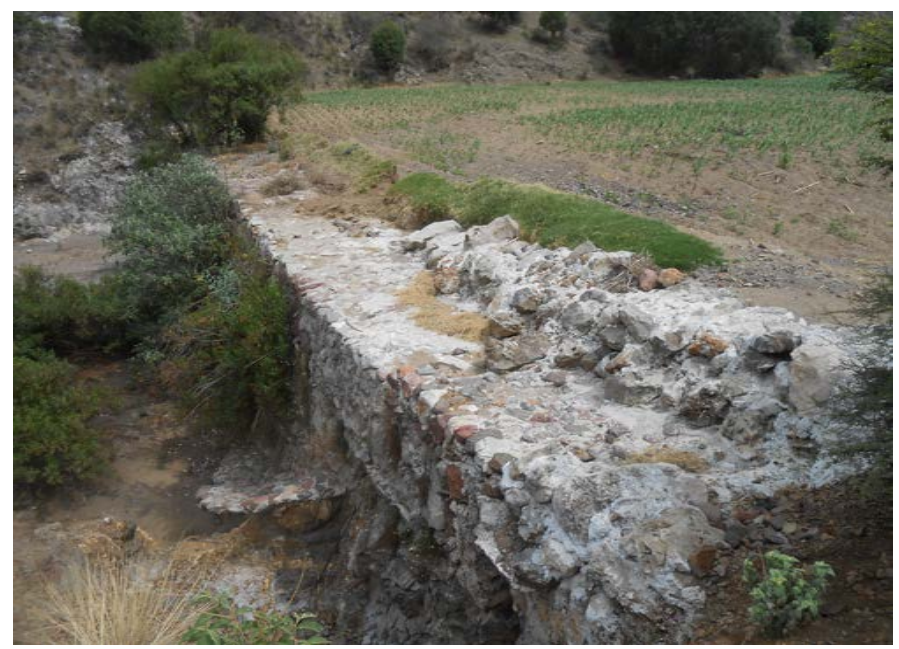

Figure 6. El Pedregal dam, spillway water curtain maintenance (Galindo 2015).

October, and grazing on beddings in the months of November and December.

Such situation is possible because of the biodiversity that the ejidatarios handle of the study area. Varieties of Chalqueño corn of long or short cycle depending on the cultivating place; being the dams where the first mentioned is planted due to its resistance to drought, floods or early frosts, according to what the locals say.

The same applies to beans which are commonly known as May Flower and Franciscan. In the case of potato variety, they use the variety they refer to as papa corriente (common potato) and its use consists in leaving some of the existing in the ground to be harvested only when it is removed with the plow in plantingor spudding time.

To conclude this section, agriculture work, which is practiced in an annual cycle and are those enunciated below, is superficially addressed.

1) Rayado or Barbecho (lined or followed): It is done in late January and early February. To do so one or the other of two types of plows that users called criolloor extranjero. The first is wooden with a steel tip and the second all-metal and with only one moldboard to the right.

2) Seeding: It starts in late February or early March and el extranjero plow is used. In this category the resembrar (replanting) is included and consist of planting again in the groove sections where the first did not come out, for which it is only necessary to use a shovel.

3) Encajonado and escarda (hoeing and spudding): In both works the soil is removed with the plow to pour on the stem of the plant, the difference between them is the biological stage in which it is located. The first is done when the plant has not exceeded 50 centimeters high, and may be between March and April, the second from April or May, when the plant has exceeded that height. In both cases the extranjero plow is used.

4) Harvest: It takes place from late September to early November and there are three ways in which this work is done later give way to grazing on beddings.

The firstconsists in segar (reap) or cut the corn plant with a machete when its vegetative stage has not come to term. The goal is to take to the plot holder's house both the plant and the cob to allow it to mature and postharvest use the resulting fodder to feed livestock taken into the corral.

The second is to cut the corn plant when the cob is not mature leaving on the ground small piles or brazadas of the plant until it completely dries and the product reaches the necessary maturity. At this time , the holder of each plot makes the harvest or deshoje of the cob and one part or the total of the stubble is left for grazing their cattle either sheep, goats, or the oxen that pull the yoke .

The third type of harvest is to leave corn plants in the ground until the cob reaches maturity and the deshoje or harvesting without the need of cutting the plant, and once this work is done the holder of the plot puts his animals in for grazing.

\section{Staking Plots and Lifting Dams}

There are three basic tasks that demand coordinated work by the socios in each of the two dams that are in 
common use: maintaining the walls and respective spillway water curtain, the practice of all agricultural work at the same pace and time in a cycle or calendar year, and the introduction of stakes to delimit the agricultural space according to the number of grooves that corresponds to each of the socios.

1) Maintenance and rehabilitation of presas: as already stated, the goal is to lift the height of the curtains on the particular dams and the task involves pasting stones with a mixture made of cement, lime, sand and water.

Of these, two tasks, rehabilitation is the most common, said by local people. It is held every three or five years, that does not mean that this is not done on a regular basis and not on a fixed date. This task becomes apparent when the runoff drags with it a small fraction of either curtains or walls and in such a situation the members of the respective presa decide to give the necessary maintenance to prevent loss of soil, so the goal is to repair the affected area and leave at the same level the curtain or wall in question. To do all the necessary, activities are organized by members and only they participate in verification.

Maintenance consists in giving it a levantón (increase the height) to each of the spillway water curtains which are located at the end of each of the plains formed by dams. Unlike the previous one, this task does not imply that any avenue of water has collapsed part of a curtain on specific, so simple that the task is, just only when the level of crop field is equal to the structure that prevents step runoff, and the objective is to increase the height of that at least 50 centimeters in every 15 or 18 to ensure retention of soil (Figure 7 and Figure 8).

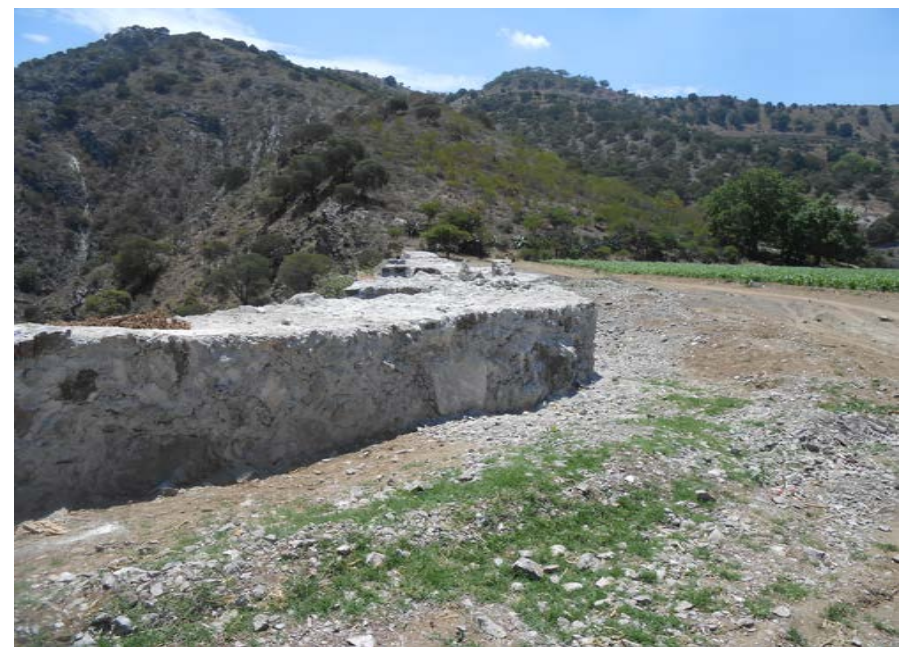

Figure 7. El Saucillo dam, augmentation of a spillway water curtain (Galindo 2015).

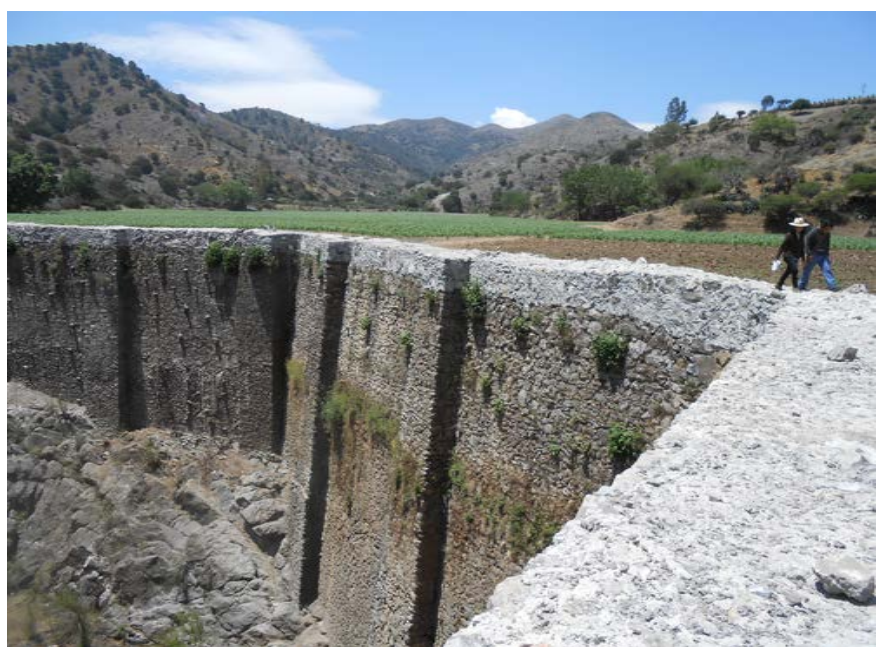

Figure 8. El Saucillo dam, augmentation of a spillway water curtain (Galindo 2015). 
2) Demarcate plots furrow with the introduction of stakes: as already mentioned, this is a recurring practice since the agrarian distribution of the last century. For this, branches of trees surrounding the contours of dams are cut down to make wooden stakes and introduce them into the soil and thus delimit a plot of another according to the number of grooves.

Such tasks are done between January and February each year, before plowing the land and then perform planting. While verification does not demand the meeting of all members of a dam at the same time, it is necessary to be done in the presence of the holder of the adjacent plot to agree the limit just before starting with the fallow.

Once such an agreement is made, the stakes remain buried throughout the year or agricultural cycle, however, it is possible that they are moved and even with drawn by the plow during the escarda. Such a situation apparently does not generate conflicts and that year after year the limit of the plots is determined by seeding furrows (Figures 9-11).

On the contrary, it happens in some conflict points where, to demarcate plots, limits are confirmed by painting a red stripe with spray paint on a stone or stones set at each end of the dam.

3) Agricultural practices: the described management system requires a minimum of agreements to facilitate the cultivation of the field. As it is evident, the most important is the furrow division and matching successive stages of the agricultural cycle.

Thus, as already indicated, the entire area comprising the plains gained from the dry stream must be at rest

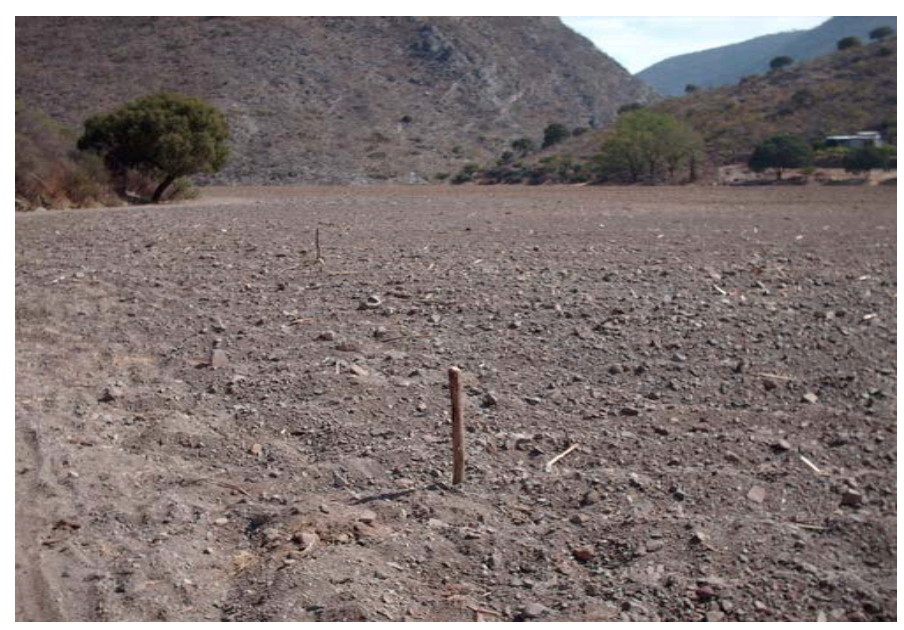

Figure 9. Sequence of stakes in the interiorof the Saucillo dam (Galindo 2015).

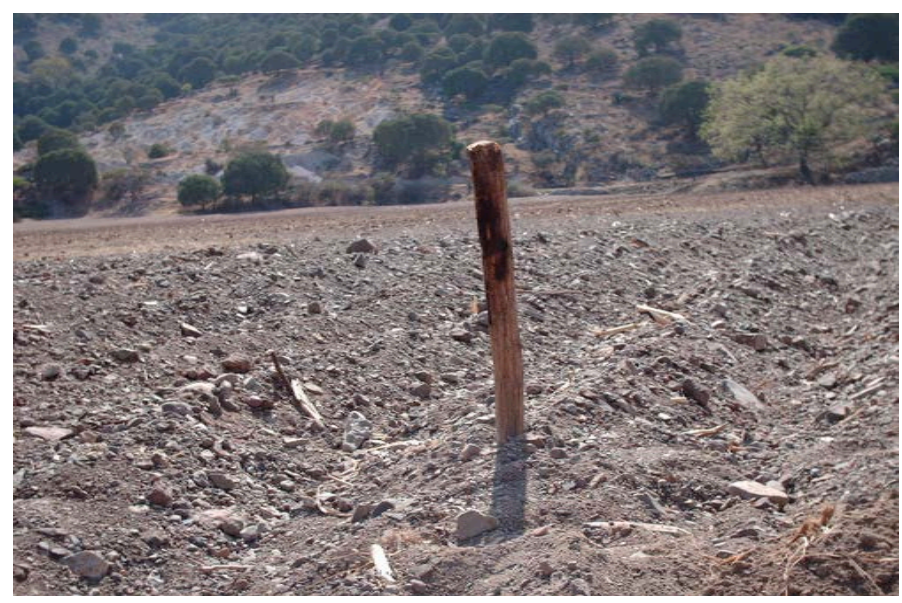

Figure 10. Sequence of stakes in the interior of the Saucillo dam (Galindo 2015). 


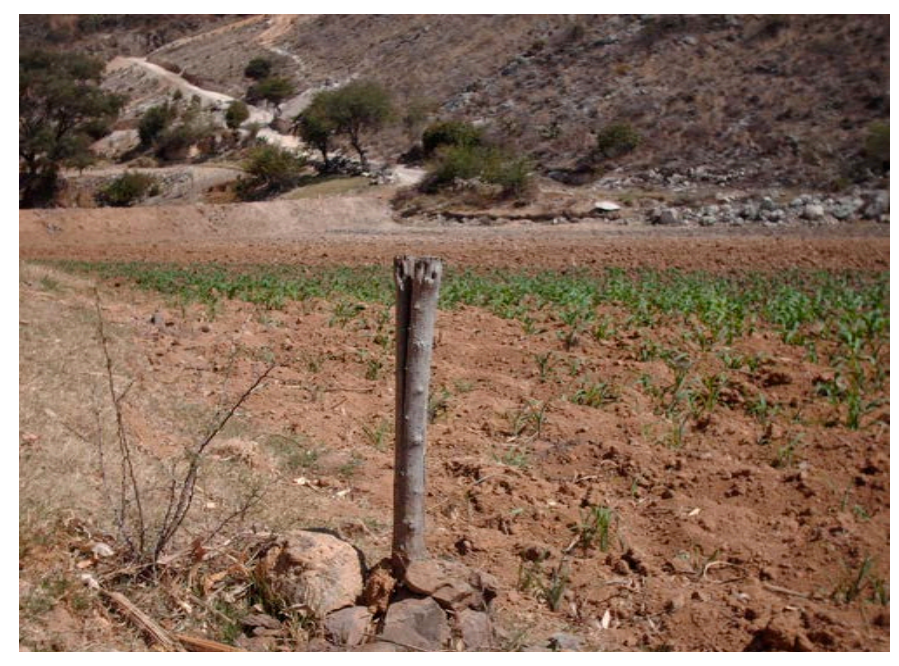

Figure 11. Sequence of stakes in the interior of the Saucillo dam (Galindo 2015).

with grazing, milpas, or fallow at the same time, and a factor that contributes decisively to this is the use of the yoke pulled by oxen.

According to observations on the field, the narrowness of the furrows prevents practices such as follows, planting or spudding are carried out with an agricultural tractor without damaging one or more furrows of the adjacent plots are affected on the left or right bands respectively. (Figure 12 and Figure 13).

Therefore, we can ensure that if the use of the yoke can be interpreted by the visitor as a technological limitation; in practice it is an advantage and even more so when you consider that the plow and animal traction occupies only three times a year and for a small number of rows.

While almost all ejidatarios have their own team, another common practice is sharecropping and is presented in very special cases, in case of illness, when the older children have migrated, or when there are no sons for handling trunk of oxen. So, for the gañan, those who lead the yoke for forrow, planting or spudding, is given in exchange for their work, a number of grooves to harvest corn obtained from them.

Another recurring situation is to hire a team to perform the tasks mentioned, the cost per day goes up to 300 pesos per day, and in order to complete the 60 or 90 furrows on a daily wage, it is necessary to work plots together with two or three socios, the latter, regardless of the physical space where the plots are located.

\section{Items for Discussion}

So far it is clear that the permanence of the traditional technology studied is the product of a series of agreements and not necessarily written rules. Such is the case of allowing flow runoff downstream once a dam has reached its absorption capacity, the division furrow of various agricultural space gained from rivers and intermittent streams, maintenance and rehabilitation in the spillway water curtain, the need to continue the same pace in the agricultural practices of a cycle or calendar year, and the freedom that allows the entry and exit of animals into dams either for grazing, farming or harvest.

Such situations, paraphrasing Bloch [29], along with the recurring use of oxen influence significantly the collective management of systems found on field, which can also be categorized as resources commonly used in terms defined by Ostrom [8].

Regarding the water conservancy and agricultural practices, it can be ensured that it is a little unconventional system of irrigation. This is because both possession and the use of the three dams mentioned are given separately, but together they make up a larger system defined by the micro river basin the Milpitas with its two tributaries, El Piña and El Pedregal ravines, respectively.

Thus, if the system lacksheadwork, it has a defined catchment area and is the one that surrounds the watershed of the basin with their respective strands in the south, east and west.

In the absence of a permanent water source, as already mentioned, once being on field, it is only possible to observe this irrigation practice if pouring rain happens with the capacity to flood cultivation areas, and this 


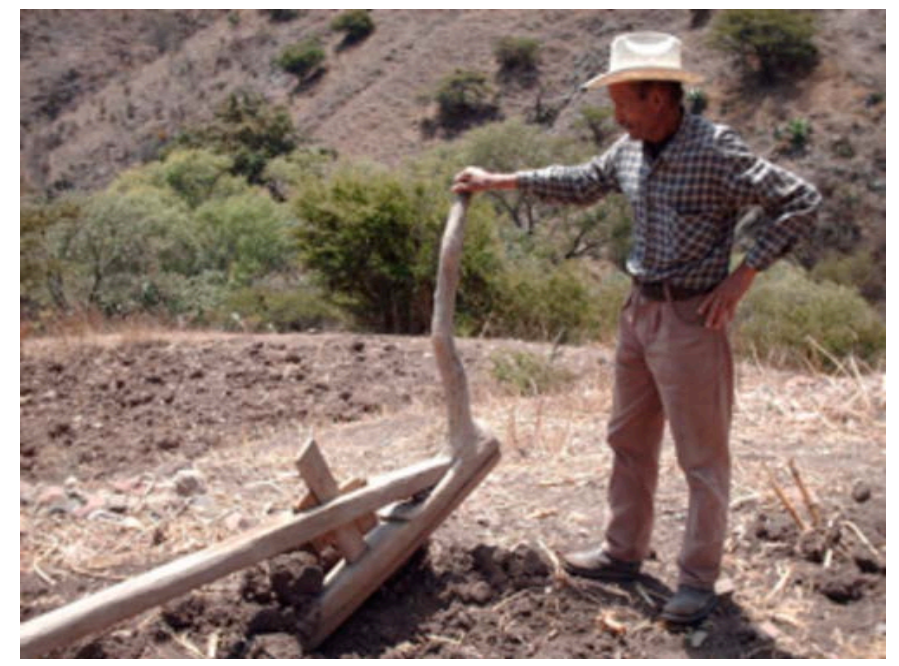

Figure 12. Partial view of a creole plow (Galindo, 2014).

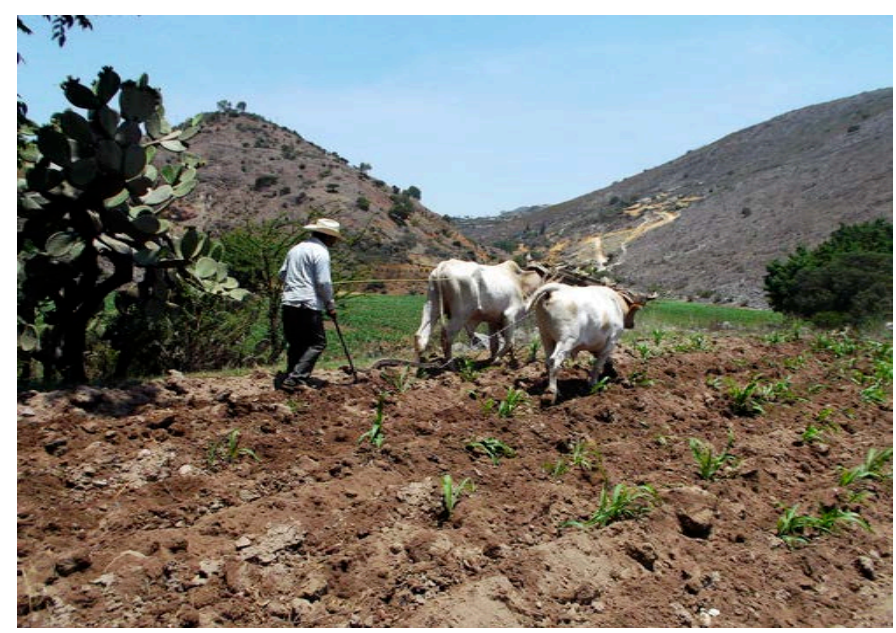

Figure 13. Hoeing corn whit a foreing plow (Galindo, 2014).

phenomenon occurs only two or three times a year.

It should be emphasized that there are no canals to bring in water and empty their surplus. This process occurs throughout the agricultural space gained from the dry streams, that is, rainwater turned into runoff is brought into the plots within the walls and once saturated it begins to overflow downstream through their respective spillway watercurtain.

Regarding the scale or the size of the system, it can be said that on the land what stands out is the monumentally of the Saucillo dam and artificial plains gained from the intermittent streams, but altogether the Palma, the Pedregal, and the Saucillo damsdo not exceed one hundred hectares. However the irrigated area, in the manner described, it is important to emphasize the autonomy of this type of irrigators from the state, and from observations on the field, it can be ensured that decision-makings for the construction and maintenance as well as inclusion agreements or sanctions rests solely among the socios of each of the respective presas.

Finally, it is important to emphasize that although the addressed case does not correspond to conventional irrigation, the methodology developed for the study is relevant to unconventional irrigation. In other words, it is possible to identify tasks always present, but their execution demands other types of specialization of the users and other periodicity in their occurrence.

\section{Conclusions}

By the observed on field, we can say that we are facing a type of small, unconventional irrigation, and its way to 
irrigate is only possible when torrential rains occur with the ability to produce significant runoff in order to flood all the plains gained from rivers and intermittent streams.

Regarding the continuity of the described system, it is worth to clarify that it depends on the permanence of the technique known locally as presas and their respective height increase of the walls and spillway water curtains which prevent the runoff paths, in the words of the local people levantar la presa.

As described thus far, retention of soil and runoff requires agreements and collective actions by ejidatario holders of the two dams that are held in common use. This situation was not necessary in the times of the hacienda where one person had owned the entire system.

Therefore, we can say that the continuation of such a system and its use in the style of open and elongated fields have several explanations. One of them is social type and timeshare of the presas, and the other, of a technical nature, which is reflected in the need to carry out at the same time agriculture work to establish the milpa.

So far exposed there are enough elements to ensure that arrangements are social rather than ecological factors, which allow the presence of milpa cultivation in open and elongated plots in the mountain ranges of Actopan.

And that the latter contributes decisively the free entry and exit of animals for grazing or for agricultural work in different plots located within the dams.

While in the case of grazing cattle of each socio grazes on the respective plot and even the cattle are tied strategically to not invade neighboring furrows. To make this possible, it is necessary the presence of open fields and grazing on livestock beddings between December and January.

Finally, it only remains to say that the case of Saucillo is one of many that are repeated on both sides of the watershed of the Actopan and Amajac Rivers. Therefore, the study of spatial distribution of the irrigation technique and its historical development is pending, as well as its regional impact in catching soil and water, as well as the environmental benefits generated by agriculture works practiced by local farmers.

\section{Acknowledgements}

To the Ejidales authorities of El Saucillo for the facilities provided during the fieldwork, the financing of PROMEP-DSA-PROJECT/103.5/14/7114 Irrigation and peri-urban agriculture in Pachuca, XIX and XX centuries for the final drafting of this article.

\section{References}

[1] Witffogel, K. [1957] (1966) Despotismo oriental: Estudio comparativo del poder totalitario [Oriental Despotism: A Comparative Study of Totalitarian Power]. Guadarrama.

[2] Glick, T.F. (1970) Irrigation and Society in Medieval Valencia. Harvard University Press, Cambridge. http://dx.doi.org/10.4159/harvard.9780674281806

[3] Maass, A. and Anderson, R. (1978) Y el desierto se regocijará... conflicto y justicia en las zonas áridas: introducción [And the Desert Shall Rejoice... Conflict and Justice in Arid Areas: Introduction]. In: Martínez, T. and Palerm, J., Eds., Antología sobre pequeño riego [Anthology on Small Irrigation], Volume 1, Colegio de Postgraduados, Mexico, 221240.

[4] Kelly, W. (1983) Concepts in the Anthropological Study of Irrigation. American Anthropologist, New Series, 85, 886-888. https://webspace.yale.edu/wwkelly/pubs-archive/WWK 1983 AA 85-4.pdf

[5] Vaidyanathan, A. [1985] (2009) Instituciones de control del agua y agricultura: Una perspectiva comparativa [Water Control Institutions and Agriculture: A Comparative Perspective]. In: Palerm, J. and Martínez, T., Eds., Aventuras con el agua. La administración del agua de riego: Historia y teoría [Adventures with Water. Water Management Irrigation: History and Theory], Colegio de Postgraduados México, 79-162.

[6] Worster, D. (1985) Rivers of Empire. Water, Aridity, and the Growth the American West. Pantheon Books, New York.

[7] Hunt, R. (1988) Sistemas de riego por canales: tamaño del sistema y estructura de la autoridad [Canal Irrigation Systems: System Size and Authority Structure]. In: Martínez, T. and Palerm, J., Eds., Antología sobre pequeño riego [Anthology on Small Irrigation], Colegio de Postgraduados, Mexico, 221-260. http://www.academia.edu/13394352/Antolog\%C3\%ADa_sobre_pequeño_riego._vol._I

[8] Ostrom, E. [1990] (2000) El gobierno de los bienes comunes [The Governant of Commons]. Fondo de Cultura Económica, Mexico.

[9] Lansing, J.S. (1991) Priests and Programmers. Technologies of Power in the Engineered Lanscape of Bali. Princeton Univerity Press, New Jersey.

[10] Palerm, J. (2002) Introducción [Introduction]. In: Palerm, J., Ed., Antología Sobre pequeño riego [Anthology on Small 
Irrigation], Volume 3, Sistemas de riego no convencionales [Unconventional Irrigation Systems], Colegio de Postgraduados, Mexico, 1-16.

https://www.researchgate.net/publication/262415060_Antologia_sobre_pequeno_riego_vol_III_Sistemas_de_riego_no _convencionales

[11] Palerm, J. (2005) Gobierno y administración de sistemas de riego. Región y Sociedad [Government and Administration of Irrigation Systems. Region and Society]. XVII, 34, 3-33.http://lanic.utexas.edu/project/etext/colson/34/1.pdf

[12] Erickson, C.L. (2006) Intensification, Political Economy, and the Farming Community. In Defense of Bottom-Up Perspective of the Past. In: Marcus, J. and Stanish, Ch., Eds., Agricultural Strategies, Cotsen Institute of Archeology, University of California, Los Angeles, 334-363.

[13] Palerm, J. (2015) El autogobierno de sistemas de riego: Caracterización de la diversidad [Self-Government Irrigation Systems: Characterization of Diversity]. Academia Colombiana de Ciencias Exactas, Físicas y Naturales, Colombia. http://www.academia.edu/18958957/El_autogobierno_de_sistemas_de_riego_caracterización_de_la_diversidad

[14] Palerm, J. and Martínez, T. (1997) Introducción: La investigación sobre pequeño riego en México [Introduction: Research on Small Irrigation in Mexico]. In: Martínez, T. and Palerm, J., Eds., Antología sobre pequeño riego [Anthology on Small Irrigation], Volume 1, Colegio de Postgraduados, Mexico, 1-42. https://www.academia.edu/13394352/Antolog\%C3\%ADa_sobre_pequeño_riego._vol._I

[15] Palerm, J., Ed. (2002) Antología sobre pequeño riego [Anthology on Small Irrigation]. Volume 3, Sistemas de riego no convencionales [Unconventional Irrigation Systems], Colegio de Postgraduados, Mexico, 1-16.

https://www.researchgate.net/publication/262415060_Antologia_sobre_pequeno_riego_vol_III_Sistemas_de_riego_no convencionales

[16] Fortanelli, J. (2007) Jardines en el desierto. Agricultura de riego, tradicional y moderna en el altiplano potosino [Gardens in the Desert. Irrigated Agriculture, Traditional and Modern in the Potosino Plateau]. Universdiad Autónoma de San Luis Potosí, Mexico.

[17] Evenari, M., Shanan, L. and Tadmor, N. (1982) The Negev: The Challenge of a Desert. Harvard University Press, Cambridge.

[18] Oropeza, J.L., Rubio, E. and Ríos, J.D. (2002) Manejo de escurrimientos superficiales en las regiones áridas y semiáridas de México [Management of Surface Runoff in Arid and Semiarid Regions of Mexico]. In: Palerm, J., Ed., Antología sobre pequeño riego [Anthology on Small Irrigation]. Volumen III Sistemas de riego no convencionales [Unconventional Irrigation Systems], Colegio de Postgraduados, Mexico, 341-360.

[19] Sanders, W.T. (1957) Tierra y agua [Earth and Water]: A Study of the Ecological Factors in the Development of Mesoamerican Civilizations. PhD Dissertation, Department of Anthropology, Harvard University, Cambridge.

[20] MacNeish, R.S. (1958) Preliminary Archaeological Investigations in the Sierra de Tamaulipas, México. Transactions of the American Philosophical Society, 48, 1-210. http://dx.doi.org/10.2307/1005840

[21] Spores, R. (1969) Settlement, Farming Technology, and Environment in the Nochixtlan Valley. Science, 166, 557-569. http://dx.doi.org/10.1126/science.166.3905.557

[22] West, R.C. (1970) Population Densities and Agricultural Practices in Pre-Columbian Mexico, with Special Emphasis on Semi-Terracing. Verhandlungen des XXXVIII Internationalen Amerikanistenkongresses, Stuttgart-München, 2, 367.

[23] Donkin, R.A. (1979) Agricultural Terracing in the Aboriginal New World. The University of Arizona Press, Tucson.

[24] Rojas, T. (1988) Las siembras de ayer: La agricultura indígena del siglo XVI [Plantings of Yesterday: Indian Agriculture in the 16th Century]. Secretaría de Educación Pública, Mexico.

[25] Martínez, T. (1998) La diáspora tlaxcalteca. Colonización agrícola del norte mexicano [The Tlaxcalteca Diaspora. Agricultural Colonization of Northern Mexico]. Ediciones del Gobierno del Estado de Tlaxcala, Mexico.

[26] Rivas, M. (2008) El sistema de jollas una técnica de riego no convencional en la Mixteca [The Jollassystem, an Unconventional Irrigation Technique in the Mixteca]. Boletín del Archivo Histórico del Agua, Año 13, Número especial Captación de agua de lluvia. Archivo Histórico del Agua-Comisión Nacional del Agua [Bulletin of the Historical Archive of Water], Mexico, 6-16.

[27] Galindo, E. (2008) Captación de agua de lluvia y retención de suelo en jollas en el parte aguas de las cuencas de los ríos Actopan y Amajac. Boletín del Archivo Histórico del Agua [Capturing Rainwater and Soil Retention in Jollas in the Basin Waters of the Actopan and Amajac Rivers. Bulletin of the Historical Archive of Water]. Año 13, Número especial Captación de agua de lluvia, Archivo Histórico del Agua-Comisión Nacional del Agua, Mexico, 17-20.

[28] Leigh, D., Kowalewski, S. and Holdridge, G. (2013) 3400 Years of Agricultural Engineering in Mesoamerica: Lama-Bordos of the Mixteca Alta, Oaxaca, México. Journal of Archaeological Science, 40, 4107-4111. http://dx.doi.org/10.1016/j.jas.2013.05.009

[29] Bloch, M. [1952] (1978) La historia rural francesa. Caracteres originales [French Rural History. Original Characters]. Editorial Crítica, Spain. 
[30] INEGI (2003) Carta topográfica F14D71 [Topographic Map F14D71]. Actopan Escala 1:50 000, Instituto Nacional de Estadística Geografía e Informática, Mexico.

[31] INEGI (2003) Carta hidrológica de aguas superficiales F14-11 [Hydrologic Map of Surface Water F14-11]. Pachuca Escala 1:250 000, Instituto Nacional de Estadística Geografía e Informática, Mexico.

[32] Padrón e Historial de Núcleos Agrarios [Census and History of Agriculture Core] (2015) Registro Agrario Nacional, Mexico. http://phina.ran.gob.mx/phina2/

[33] Rojas, T. (1985) La tecnología agrícola mesoamericana en el siglo XVI [Mesoamerican Agricultural Technology in the 16th Century]. In: Rojas, T. and Sanders, W.T., Eds., Historia de la agricultura época prehispánica siglo XVI [Agriculture History Prehispanic Era 16th Century], Instituto Nacional de Antropología e Historia, Mexico, 129-230. 